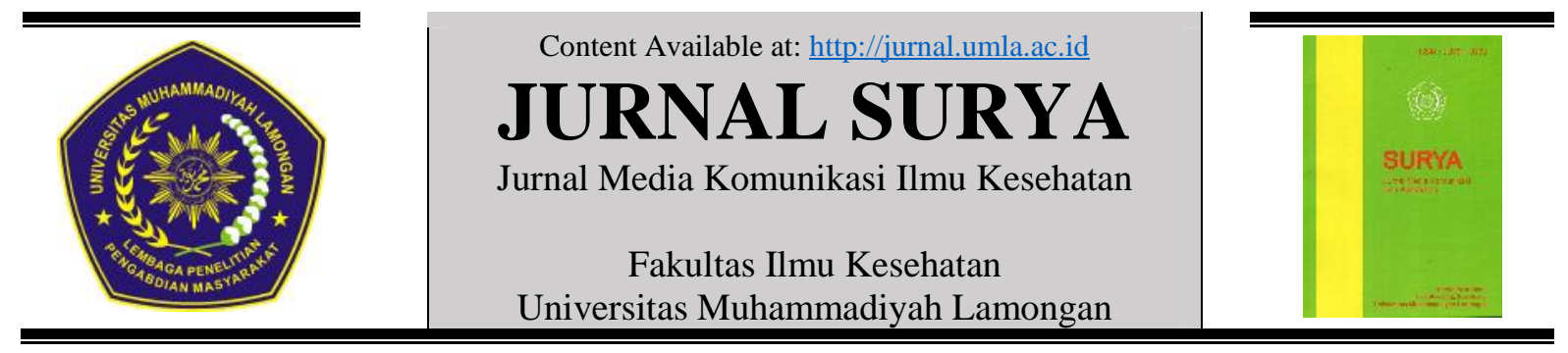

\title{
Lama Penggunaan Implant terhadap Siklus dan Periode Menstruasi di PMB Kirang Naning Amd.Keb. Desa Kedali Kecamatan Pucuk Kabupaten Lamongan \\ Diah Eko Martini ${ }^{1}$, Eny Rachmawati ${ }^{2}$ \\ ${ }^{1}$ Staf Pengajar Prodi S1 Keperawatan Universitas Muhammadiyah Lamongan \\ ${ }^{2}$ Mahasiswa Prodi Sl Keperawatan Universitas Muhammadiyah Lamongan
}

\section{ARTIKEL INFO}

\section{Article History:}

SM at 11-06-2020

$R$ at $15-06-2020$

$P B$ at 25-06-2020

\section{Kata Kunci:}

Lama penggunaan implant

Siklus

Lama menstruasi

Korespondensi Penulis: diahekomartini@gmail.com

\section{ABSTRAK}

Background: Perubahan pola menstruasi merupakan efek samping yang umum pada penggunaan kontrasepsi implant, hal ini merupakan faktor utama akseptor implant menghentikan menggunakan metode ini, namun belum bisa dipastikan sejak kapan perubahan pola menstruasi ini mulai terjadi.

Objectives: Tujuan dari penelitian ini adalah untuk mengetahui lama penggunaan implant terhadap pola menstruasi di PMB Kirang Naning Amd.Keb Desa Kedali Kecamatan Pucuk Kabupaten Lamongan.

Design: Desain penelitian ini menggunakan analtik dengan pendekatan cross sectional, jumlah populasi sebanyak 35 responden dengan besar sampel sebesar 33 responden, teknik yang di ambil dengan simple random sampling. Instrumen penelitian menggunakan kuesioner. Uji statistic menggunakan uji chi-square dengan tingkat kemaknaan 0,05 .

Results: Hasil penelitian menunjukkan pada siklus menstruasi akseptor kb implant 3 bulan-1 tahun mengalami siklus menstruasi normal sedangkan $>1$ tahun sebagian besar $(71,4 \%)$ mengalami amenorea, sedangkan lama menstruasi akseptor kb implant 3 bulan-1 tahun mengalami lama menstruasi normal, sedangkan $>1$ tahun hampir seluruhnya $(80,0 \%)$ mengalami hiperminorea. dari uji statistik diperoleh Dimana nilai P 0,001 dimana $\mathrm{P}<0,05$ artinya $\mathrm{H} 0$ ditolak dan $\mathrm{H} 1$ diterima.

Conclusions: ada hubungan lama penggunaan implant dengan siklus menstruasi. $\mathrm{P} 0,011$ dimana $\mathrm{P}<0,05$ artinya H0 ditolak dan H1 diterima sehingga ada hubungan lama penggunaan implant dengan lama menstruasi. Rekomendasi dari penelitian ini, perlu adanya informasi tentang lama penggunaan implant dengan cara memberikan konseling sebelum pemilihan metode kontrasepsi. 
PENDAHULUAN

Implant merupakan suatu kotrasepsi yang mengandung levonogestrel yang di bungkus dalam kapsulsilasic-silicone atau polydimethylsiloxane dan dimasukan di bawah kulit (Sarwono Prawidharjo, 2011). Penggunaan kontrasepsi ini dipercaya sangat efektif untuk mencegah kehamilan dimana angka kegagalannya kurang dari 1 per 100 wanita pertahun dalam 5 tahun pertama (Hartanto, 2010). Kontrasepsi ini bekerja dengan cara menebalkan mucus serviks sehingga tidak dapat dilewati oleh sperma, selain itu implant progrestin juga menekan pengeluaran Follicle Stimulation Hormone(FSH) dan Lutenizing Hormone (LH) dari hipotalamus (French, 2015) Seperti halnya kontrasepsi yang lain, penggunaan implant juga menyebabkan efek samping perdarahan atau gangguan menstruasi. Secara umum pada wanita, gangguan menstruasi lebih sering berupa haid yang tidak teratur, terutama 3 tahun pertama setelah datangnya menarche, kemudian disusul oleh menorhagia dan dismenorea (Biran A, 2014), namun pada kontrasepsi implant pola pendarahan menjadi tidak dapat diprediksi dan tidak teratur, sesekali dengan pendarahan yang terjadi lebih sering dan atau menjadi berkepanjangan atau jarang, bahkan dengan episode amenorea. Total volume yang diukur kehilangan darah endometrium pada wanita menggunakan subdermal implan progestogen biasanya jauh lebih kecil dari kehilangan darah saat menstruasi. Meskipun perubahan ini tidak memiliki efek serius pada kesehatan, namun bisa mengganggu aktivitas sehari-hari dan berdampak pada wanita kesejahteraan umum. Selain itu Penyimpangan yang terjadi merupakan alasan pentinguntuk penghentian pengobatan dengan implan khusus progestogen ini. (Diana Mansour, 2008). Menurut Penelitian Anggia dan Mahmudah (2013) gangguan menstruasi yang dialami responden sebelum pemakaian kontrasepsi, setelah, dan pada saat ini adalah gangguan pola menstruasi $36,5 \%$, gangguan lama menstruasi 35,3\%, dan gangguan siklus menstruasi $45,9 \%$. Sejalan dengan penelitian tersebut, sebuah studi dari Maharani (2010) menunjukkan bahwa keluhan menstruasi yang dirasakan wanita yang menggunakan implan adalah $73 \%$ tidak teratur siklus menstruasinya dan $27 \%$ teratur siklus menstruasinya. Menurut data Kemenkes RI di pada tahun 2016 di ketahui bahwa, wanita yang mengalami gangguan pola menstruasi tidak normal sebanyak $(61,8 \%)$. Sedangkan yang mengalami menstruasi normal sebanyak $(38,2 \%)$. Berdasarkan survey awal yang dilakukan pada bulan oktober 2018 di PMB Kirang Naning, Amd.Keb di Desa Kedali Kecamatan Pucuk Kabupaten Lamongan, dari 10 responden tersebut yang mengalami gangguan pola menstruasi sebanyak 8 orang (80\%) mengalami ketidakteraturan siklus menstruasi dan sebanyak 2 orang (20\%) yang siklus menstruasi teratur. $80 \%$ tersebut mengalami gangguan menstruasi di antaranya adalah aminorhe, perdarahan bercak (spotting), hiprmenorea, oligomenorea. Ada beberapa faktor yang mempengaruhi gangguan pola menstruasi selain faktor hormonal yang sudah di jelaskan di atas, faktor lain di antaranya adalah psikis, emosi, gizi, usia, stress, penyakit ginekologi, jenis kontrasepsi, dan lama penggunaan kontrasepsi (Hestiantoro 2012). Dalam pengguna jangka Panjang implan dapat menimbulkan kekeringan pada vagina, gangguan emosi, nevorsitas dan jerawat (Everett, 2010).

Hormone progesterone dapat mempengaruhi panjang dan pendeknya siklus menstruasi, siklus menstruasi sangat dipengaruhi oleh hormon wanita yaitu ekstrogen dan progesterone, kedua hormone bersifat fluktuatif (dapat berubah-ubah), sedikit saja terjadi perubahahan keseimbangan kedua hormone tersebut maka dapat terjadi ketidakteraturan siklus menstruasi yang berupa lebih panjang, lebih pendek, jumlah sedikit, jumlah banyak (Baziad, 2014). Sejumlah gangguan pola haid ini akan terjadi pada tahun pertama penggunaan, kira-kira $80 \%$ pengguna. Perubahan tersebut meliputi interval antar perdarahan, durasi dan volume aliran darah, serta spotting (bercak-bercak perdarahan). Oligomenore dan amenore juga terjadi tetapi tidak sering. Kurang dari $10 \%$ setelah tahun pertama.Perdarahan teratur dan memanjang biasanya terjadi pada tahun pertama. Walaupun terjadi jauh lebih jarang setelah tahun kedua, masalah perdarahan dapat terjadi pada waktu kapanpun (Hartanto, 2010). Amenorea terjadi pada $30-40 \%$ wanita pada akhir tahun pertama pemakaian; perdarahan 
tidak teratur terjadi pada sekitar 50\% wanita pada pengguna kontrasepsi $>1$ tahun. Namun demikian Implant juga sering menimbulkan perdarahan bercak atau terus- menerus pada 6-9 bulan pertama dari pengguna implant, perdarahan yang lama selama beberapa bulan pertama pemakaian, perdarahan atau bercak perdarahan di antara siklus haid, lamanya perdarahan, tidak mengalami perdarahan atau bercak perdarahan sama sekali selama beberapa bulan (amenorea). Hal ini sesuai dengan yang disampaikan Hartanto bahwa efek samping yang paling utama dari Implant adalah perubahan pola menstruasi yang terjadi pada hampir 60 persen akseptor dalam tahun pertama setelah insersi pemasangan (Hartanto, 2010).

Upaya yang dapat dilakukan untuk meminimalisir efek samping pada penggunaan $\mathrm{KB}$ implant terutama pada gangguan pola menstruasi maka diperlukan berbagai macam upaya di antaranya adalah aseptor KB agar sering kontrol pada petugas kesehatan setiap waktu yang diinginkan. Guna memperoleh konseling maupun pemeriksaan secara intensif tentang alat kontrasepsi sehingga program pemerintah tentang KB dapat berjalan dengan baik. Selain itu pengetahuan yang baik tentang alat kontrasepsi perlu di tingkatkan sehingga dapat memberikan pemahaman bagi aseptor KB sehingga adanya keluhan dari pemakaian aseptor KB implant dapat sedikit berkurang.

\section{METODE}

Jenis penelitian analtik dengan rancangan cross-sectional dengan populasi adalah akseptor KB implant di PMB kirang naning Amd.Keb Desa Kedali Kecamatan Pucuk Kabupaten Lamongan. Teknik sampling yang digunakan adalah simple random sampling. Instrumen penelitian ini menggunakan kuesioner dengan teknik wawancara mengenai pola menstruasi yakni siklus dan lama menstruasi. Data dianalisis menggunakan menggunakan uji chi-square dengan SPSS versi 22 for windows dengan $\alpha$ sebesar 0.05

\section{HASIL PENELITIAN}

1. Karakteristik umur ibu

Tabel 1 Karakteristik umur ibu di PMB Kirang Naning Amd.Keb

\begin{tabular}{llcc}
\hline No & \multicolumn{1}{c}{ Umur } & F & \% \\
\hline 1 & $<20$ tahun & 3 & 9,1 \\
2 & 20-35 tahun & 23 & 69,7 \\
3 & $>35$ tahun & 7 & 21,2 \\
\hline & Jumlah & $\mathbf{3 3}$ & $\mathbf{1 0 0}$ \\
\hline & Berdasarkan hasil tabel 1 di dapatkan
\end{tabular}

sebagian besar atau $(69,7 \%)$ ibu berumur 2035 tahun.

2. Karakteristik pendidikan ibu

Tabel 2 Karakteristik pendidikan ibu di PMB

Kirang Naning Amd.Keb

\begin{tabular}{lcccc}
\hline No & Pendidikan & F & \% \\
\hline 1 & SD & 6 & 18,2 \\
2 & SMP & 8 & 24,2 \\
3 & SMA & 14 & 42,4 & \\
4 & PT & 5 & 15,2 & \\
\hline & Jumlah & $\mathbf{3 3}$ & $\mathbf{1 0 0}$ & \\
\hline & Berdasarkan & hasil & tabel & 2
\end{tabular}

menunjukkan bahwa hampir sebagian atau $(42,4 \%)$ ibu berpendidikan SMA.

3. karakteristik pekerjaan ibu

Tabel 3 Karakteristik pekerjaan ibu di PMB Kirang Naning Amd.Keb

\begin{tabular}{|c|c|c|c|}
\hline No & Pekerjaan & $\mathbf{F}$ & $\%$ \\
\hline 1 & Tidak bekerja & 5 & 15,1 \\
\hline 2 & Tani & 10 & 30,3 \\
\hline 3 & Wiraswasta & 16 & 48,5 \\
\hline 4 & Pns /Polri & 2 & 6,1 \\
\hline & Jumlah & 33 & 100 \\
\hline
\end{tabular}

bahwa hampir sebagian atau $(48,5 \%)$ ibu bekerja sebagai Wiraswasta.

4. lama penggunaan implant

Tabel 4 Lama penggunaan implant di PMB Kirang Naning Amd.Keb

\begin{tabular}{clcc}
\hline No & Lama pemakaian & F & \% \\
\hline 1 & 3 bulan- 1 tahun & 16 & 48,5 \\
2 & $>$ 1 tahun-2tahun & 10 & 30,3 \\
3 & $>$ 2tahun & 7 & 21,2 \\
\hline & Jumlah & $\mathbf{3 3}$ & $\mathbf{1 0 0}$ \\
\hline & Pada tabel di atas dapat dijelaskan
\end{tabular}

bahwa hampir sebagian atau ( 48,5\%) akseptor menggunakan kontrasepsi implant selama 3 bulan- 1 tahun, sedangkan sebagian 
kecil atau (21,2\%) akseptor menggunakan kontrasepsi implant $>2$ tahun.

5. Siklus menstruasi

Tabel 5 Siklus mestruasi di PMB Kirang Naning Amd.Keb

\begin{tabular}{clcc}
\hline No & Siklus Menstruasi & F & \% \\
\hline 1 & Normal & 12 & 36,4 \\
2 & Polimenorea & 5 & 15,2 \\
3 & Oligomenor & 6 & 18,2 \\
4 & Amenorea & 10 & 30,3 \\
\hline & Jumlah & $\mathbf{3 3}$ & $\mathbf{1 0 0}$
\end{tabular}

Berdasarkan hasil tabel 5 diatas menunjukkan bahwa hampir sebagian atau $(36,4 \%)$ ibu yang mengalami siklus menstruasi normal, sedangkan sebagian kecil atau $(15,2 \%)$ ibu mengalami poliminorea.

6. Lama menstruasi

Tabel 6 Lama mestruasi di PMB Kirang Naning Amd.Keb

\begin{tabular}{clcc}
\hline No & Lama Menstruasi & F & \% \\
\hline 1 & Normal & 14 & 42,4 \\
2 & Hipermenorea & 16 & 48,5 \\
3 & Hipomenorea & 3 & 9,1 \\
\hline & Jumlah & $\mathbf{3 3}$ & $\mathbf{1 0 0}$ \\
\hline
\end{tabular}

Berdasarkan hasil tabel 6 diatas menunjukkan bahwa hampir sebagian atau (48,5\%) mengalami hipermenorea, sedangkan sebagian kecil atau $(9,1 \%)$ mengalami hipomenorea.

7. Hubungan lama penggunaan implant dengan siklus menstruasi

Tabel 7 Tabulasi silang hubungan lama penggunaan implant dengan siklus menstruasi pada aseptor KB implant di PMB Kirang Naning Amd.Keb.

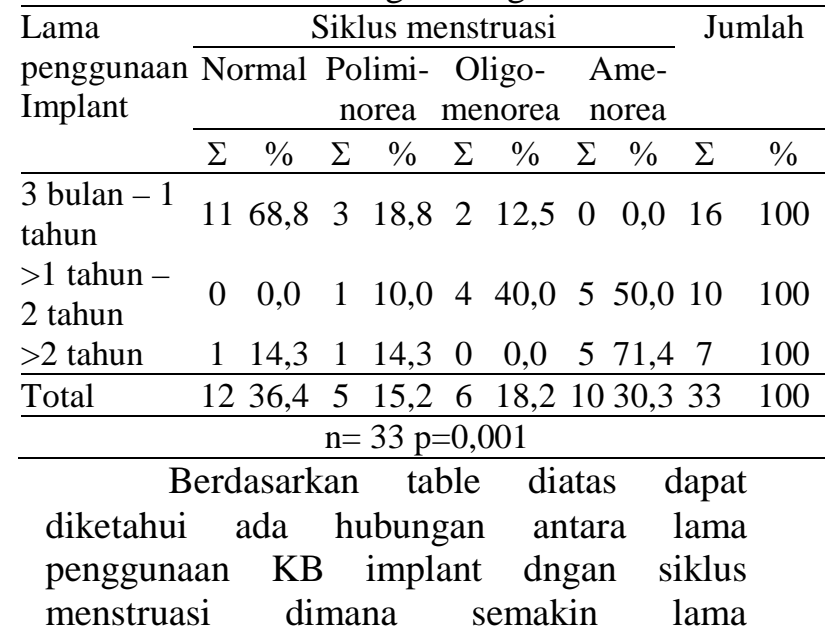

menggunakan $\mathrm{KB}$ Implant maka perubahan siklus menstruasi cenderung amenorea.

8. Hubungan lama penggunaan implant dengan lama menstruasi

Tabel 8 Tabulasi silang hubungan lama penggunaan implant dengan lama menstruasi pada aseptor $\mathrm{KB}$ implant di PMB Kirang Naning Amd.Keb Desa Kedali Kecamatan Pucuk Kabupaten Lamongan pada tahun 2019.

\begin{tabular}{|c|c|c|c|c|c|c|c|c|}
\hline \multirow{3}{*}{$\begin{array}{l}\text { Lama } \\
\text { pengunaan } \\
\text { implant }\end{array}$} & \multicolumn{6}{|c|}{ Lama menstruasi } & \multicolumn{2}{|c|}{ Jumlah } \\
\hline & \multicolumn{2}{|c|}{ Normal } & \multicolumn{4}{|c|}{ Hipermenorea Hipomenorea } & \multirow[b]{2}{*}{$\Sigma$} & \multirow[b]{2}{*}{$\%$} \\
\hline & $\Sigma$ & $\%$ & $\Sigma$ & $\%$ & $\Sigma$ & $\%$ & & \\
\hline $\begin{array}{l}\text { 3bulan- } 1 \\
\text { tahun }\end{array}$ & 11 & 68,8 & 4 & 25,0 & 1 & 6,3 & 16 & 100 \\
\hline $\begin{array}{l}>1 \text { tahun- } 2 \\
\text { tahun }\end{array}$ & 2 & 20,0 & 8 & 80,0 & 0 & 0,0 & 10 & 100 \\
\hline$>2$ tahun & 1 & 14,3 & 4 & 57,1 & 2 & 28,6 & 7 & 100 \\
\hline Total & 14 & 42,4 & 16 & 48,5 & 3 & 9,1 & 33 & 100 \\
\hline \multicolumn{9}{|c|}{$\mathrm{n}=33 \mathrm{p}=0,011$} \\
\hline \multicolumn{9}{|c|}{$\begin{array}{l}\text { dikethui bahwa ada hubungan anatara lama } \\
\text { penggunaan KB implant dengan lama } \\
\text { menstruasi di mana semakain la } \\
\text { menggunakan } \mathrm{KB} \text { implant maka resiko pola } \\
\text { menstruasinya } \\
\text { hinermenorea }\end{array}$} \\
\hline
\end{tabular}

\section{PEMBAHASAN}

\section{Lama Penggunaan Implant}

Berdasarkan fakta di Desa Kedali Kecamatan Pucuk Kabupaten Lamongan tahun 2019 hampir sebagian atau $(48,5 \%)$ akseptor $\mathrm{kb}$ implant yang memakai $\mathrm{kb}$ implant 3 bulan-1 tahun.

Menurut Sarwono Prawidharjo (2011) Implant adalah suatu kotrasepsi yang mengandung levonogestrel yang di bungkus dalam kapsul silasic-silicone (polydimethylsiloxane) dan dimasukan di bawah kulit. Menurut teori yang dikemukakan oleh Green (1980) dalam Notoatmodjo (2009) bahwa prilaku kesehatan termasuk didalamnya pemilihan atau penggunaan alat kontrasepsi dipengaruhi oleh faktor yaitu faktor predisposing (pendidikan), faktor pendukung (ketersediaan alat kesehatan, sumber informasi) serta faktor pendorong (dukungan keluarga dan tokoh masyarakat).

Berdasarkan teori di atas, faktor yang mempengaruhi seorang wanita untuk 
menggunakan metote kontrasepsi implant diantaranya pendidikan, yang mengarah ke jumlah penghasilan informasi. Berdasarkan fakta diketahui bahwa hampir sebagian akseptor pendidikan SMA telah menggunakan kotrasepsi selama 3 bulan- 1 tahun. Ibu yang berpendidikan tinggi akan lebih mudah menerima informasi mengenai kontrasepsi implant dan efek sampingnya terutama yang berkaitan dengan pola menstruasi baik dari siklus menstruasi maupun lama menstruasi sehingga tingkat kecemasan ibu tidak terlalu besar yang mempengaruhi pada lama penggunaan kontrasepsi implant, begitu pula sebaliknya. Hal ini sesuai dengan pendapat Notoatmodjo (2009) bahwa peran pendidikan adalah melakukan intervensi faktor prilaku sehingga perilaku individu, kelompok atau masyarakat sesuai dengan nilai yang berlaku. Semakin tinggi pendidikan seorang semakin mudah pula mereka menerima dan memberika informasi.

\section{Siklus Menstruasi}

Berdasarkan hasil penelitian yang di tunjukkan pada tabel 4.5 menunjukkan bahwa hampir sebagian $(36,4 \%)$ akseptor kb implant yang mengalami siklus menstruasi normal.

Menurut Sibagriang.dkk (2010) siklus menstruasi normal adalah 21-35 hari dalam setiap bulan. Sesuai dengan hasil penelitian bahwa akseptor kb implant hampir sebagian siklus menstruasinya normal antara 21-35 hari. Hasil penelitian ini sesuai dengan teori bahwa siklus menstruasi memang salah satu efek dari kontrasepsi implant, sering ditemukan siklus menstruasi yang tidak normal terutama pada lama penggunaan implant yang lebih dari 2 tahun. Beberapa wanita mungkin akan mengalami amenorea. Daniel (2018).

Menurut Hartanto (2010) Dalam penggunaan implant yang lebih dari 1 tahun dapat menimbulkan gangguan siklus amenorea, oligomenorea, gangguan emosi. Ini membuktikan bahwa hormone dalam tubuh sangat mempengaruhi siklus menstruasi. Kadar FSH yang tinggi dapat mengakibatkan terjadinya stimulasi ovarium yang berleihan (hiperstimulasi) sehingga dijumpai kadar progesteron yang sangat tinggi. Pada awal penggunaan kontrasepsi ini tidak mengalami siklus menstruasi dikarenakan hormone dalam tubuh seimbang. Dan yang mengalami siklus menstruasi ini karena ketidakseimbangan hormon.

Hasil penelitian ini sesuai dengan teori bahwa awal penggunaan kontrasepsi implant ini mengalami siklus menstruasi normal, namun setelah lebih dari 1 tahun beberapa responden mengalami siklus mentruasi beupa amenorea.

\section{Lama Menstruasi}

Berdasarkan hasil penelitian yang ditunjukkan pada tabel 4.6 menunjukkan bahwa setengah atau $(48,5 \%)$ akseptor $\mathrm{kb}$ implant yang mengalami lama menstruasi berupa hiperminorea. Hiperminorea merupakan perdarahan menstruasi dengan jumlah darah yng lebih banyak dan atau lamanya lebih lama dari normal (lebih dari 8 hari).

Hal ini disebabkan karena pengaruh dari hormon progesterone yang ada di dalam kemasan $\mathrm{kb}$ implant tersebut sehingga kebanyakan responden mengalami pola menstruasi berupa hiperminorea. Faktor yang mempengaruhi terjadinya hiperminorea ini salah satunya adalah penggunaan kontrasepsi implant.

Hal tersebut didukung dengan pendapat Baziad (2014) yang mengatakan bahwa hiperminorea umumnya terjadi pada setelah penggunaan alat kontrasepsi karena progesterone menyebabkan terbentuknya kembali pembuluh darah kapiler yang normal dengan sel sel endotel yang intek dan sel sel yang mengandung kadar glikoprotein yang cukup sehingga sel sel endotel terlindung dari kerusakan, hal ini akan mempengaruhi mekanisme kerja hormon dan lama menstruasi yang normal, perdarahan akan lebih bertambah atau banyak. Fajarsari dan Laely (2014), menemukan 35,7\% akseptor kb implant mengalami hiperminorea di wilayah kerja Puskesmas 1 Purworego Kabupaten Banjanegara.

\section{Hubungan Lama Penggunaan Implant Dengan Siklus Menstruasi}

Berdasarkan hasil uji chi-square dengan SPSS versi 22 dengan $\mathrm{n}=33$ meunjukkan hasil $\mathrm{p}=0,001$ dimana $\mathrm{p}=\langle 0,05$. Sehingga H0 ditolak dan $\mathrm{H} 1$ diterima, artinya Terdapat hubungan lama penggunaan implant dengan siklus menstruasi Di PMB Kirang 
Naning Amd.Keb Desa Kedali Kecamatan Pucuk Kabupaten Lamonga pada tahun 2019.

Berdasarkan fakta di Desa Kedali

Kecamatan Pucuk Kabupaten Lamongan tahun 2019 dapat terlihat bahwa dari 33 akseptor $\mathrm{kb}$ implant yang mengalami pola menstruasi berdasarkan siklus menstruasi sebagian besar $(71,4 \%)$ mengalami amenorea pada penggunaan implant $>2$ tahun.

Pada responden yang menggunakan implant 3 bulan - 1 tahun cenderung mengalami siklus menstruasi yang normal, semakin lama menggunakan kontrasepsi implant > 1 tahun maka cenderung mengalami siklus menstruasi berupa amenorea. Hasil penelitian ini menunjukkan bahwa semakin lama menggunakan implant maka siklus menstruasi akan cenderung mengalami amenorea. Hal tersebut karena adanya pengaruh progesteron yang digunakan untuk tujuan kontrasepsi parental, mempunyai efek progestagene yang kuat dan sangat efektif menekan kehamilan, namun jika digunakan dalam jangka waktu cukup yang lama akan menyebabkan siklus menstruasi yang tadinya normal menjadi aminorea.

Lama penggunaan kontrasepsi implant juga mempengaruhisiklus menstruasi yang dialami akseptor kb implant, apalagi pada akseptor yang menggunakan kontrasepsi lebih dari 1 tahun sebagian besar mengalami amenorea. Pendapat ini di dukung oleh teori dari Rowland (2014) yang menyatakan bahwa efek samping yang timbul dari penggunaan kontrasepsi implant adalah perubahan tidak teraturnya siklus mentruasi yang terjadi terutama lama penggunaan lebih dari 1 tahun pada pengguna kontrasepsi implant ditemukan lima puluh persen responden mengalami amenorea. Sedangkan menurut Saifudin, (2014) gangguan pola menstruasi sering ditemukan pada pengguna kontrasepsi implant terutama penggunaan yang lebih dari 1 tahun mungkin akan mengalami berhentinya menstruasisama sekali atau disebut amenorea.

\section{Hubungan Lama Penggunaan Implant dengan Menstruasi}

Berdasarkan hasil uji chi-square dengan SPSS versi 22 dengan $n=33$ meunjukkan hasil $\mathrm{p}=0,011$ dimana $\mathrm{p}=<0,05$. Sehingga H0 ditolak dan H1 diterima, artinya Terdapat hubungan lama penggunaan implant lama menstruasi Di PMB Kirang Naning Amd.Keb Desa Kedali Kecamatan Pucuk Kabupaten Lamonga pada tahun 2019. Berdasarkan fakta di Desa Kedali Kecamatan Pucuk Kabupaten Lamongan tahun 2019 dapat terlihat bahwa dari 33 akseptor $\mathrm{kb}$ implant yang mengalami pola menstruasi berdasarkan lama menstruasi hampir seluruhnya $(80,2 \%)$ mengalami hipermenorea pada penggunaan implant $>1$ tahun- 2 tahun. Pada responden yang menggunakan implant 3 bulan -1 tahun cenderung mengalami lama menstruasi yang normal, semakin lama menggunakan kontrasepsi implant $>1$ tahun maka cenderung mengalami lama menstruasi berupa hiperminorea. Hasil penelitian ini menunjukkan bahwa semakin lama menggunakan implant maka lama menstruasi akan cenderung mengalami hiperminorea. Hal tersebut karena adanya pengaruh dari kemasan kb implant yang hanya mengandung hormone progesterone saja sehingga menyebabkan lama menstruasi yang tadinya normal menjadi hiperminorea.

Menurut teori Hartanto (2010) mengatakan bahwa kontrasepsi implant yang hanya mengandung hormon progestin sehingga dapat mengalami pola menstruasi berupa hiperminorea. Penelitian ini sesuai dengan teori yang dikemukan oleh Baziad (2014) yang mengatakan bahwa hiperminorea umumnya terjadi pada setelah penggunaan alat kontrasepsi karena hormonprogesteron menyebabkan terbentuknya kembali pembuluh darah kapiler yang normal dengan sel sel endotel yang intek dan sel sel yang mengandung kadar glikoprotein yang cukup sehingga sel sel endotel terlindung dari kerusakan, hal ini akan mempengaruhi mekanisme kerja hormon dan lama menstruasi yang normal, perdarahan akan lebih bertambah atau banyak.

\section{KESIMPULAN}

\section{Kesimpulan}

Setelah penelitian menganalisis data dan melihat hasilnya maka peneliti mengambil kesimpulan sebagai berikut :

1) Ada hubungan antara lama penggunaan implant dengan lama di mana semakain la menggunakan $\mathrm{KB}$ implant maka resiko pola menstruasinya cenderung mengalami hipermenorea 
2) Ada hubungan antara lama penggunaan implant siklus menstruasi dimana semakin lama menggunakan $\mathrm{KB}$ Implant maka perubahan siklus menstruasi cenderung memiliki amenorea.

\section{Saran}

Berdasarkan Hasil penelitian ini peneliti diharapkan perawat mampu memberikan informasi atau penyuluhan tentang kontrasepsi implant yang terdiri dari manfaat, keuntungan dan efek samping dari kontrasepsi implant sehingga dapat meningkatkan pengetahuan dan meningkatkan mutu pelayanan keperawatan melalui profesionalisme keperawatan kader kesehatan dapat meningkatkan kerja sama lintas sector untuk lebih memasyarakatkan program KB fungsinya untuk memberi pelayanan kesehatan khususnya mengenai masalah kontrasepsi.

\section{DAFTAR PUSTAKA}

Anggia dan Mahmudah. 2013. Faktor-faktor yang mengetahui pengetahuan ibu tentang implant di DesaTanjung Anom.Jurnal kebidanan

Muhammadiyah Medan

Baziad. 2014. Kontrasepsi hormonal. Jakarta: Yayasan Bina Pustaka Sarwono Prawirohardjo.

Biran A. 2014 Gangguan Menstruasi Pada Remaja, Mingguan Mimbar Karya, 7

Daniel Martina,b, Craig Salea , Simon B Coopera, and Kirsty J Elliott-Salea. 2018. Period Prevalence and Perceived Side Effects of Hormonal Contraceptive Use and the Menstrual Cycle in Elite Athletes. : International Journal of Sports Physiology and Performance.

DOI: https://doi.org/10.1123/ijspp.2017$\underline{0330}$

Diana Mansour ${ }^{1}$, Tjeerd Korver, Maya Marintcheva-Petrova, Ian $\mathrm{S}$ Fraser 2008. The Effects of Implanon on Menstrual Bleeding Patterns. Eur J Contracept Reprod Health Care 2008
Jun;13 Suppl 1:13-28.

DOI: $10.1080 / 13625180801959931$

Everett. 2010. Kontrasepsi dan Kesehatan Seksual Reproduksi. Jakarta: EGA

Fajarsari dan Laely. 2014. Hubungan lama pemakaian implant dengan kejadian hiperminorea di Perumahan Petragriya Indah Purwodadi

French, V, Darney, P,2015. Implantable Contraception Glob. libr. women's med.,

(ISSN: $\quad$ 1756-2228) 2015; DOI 10.3843/GLOWM.10399

Hartanto, Hanafi. (2010). Keluarga Berencana dan Kontrasepsi. Jakarta. Pustaka Sinar Harapan

Hestiantoro (2012). Analisis Faktor-Faktor Pada Ibu Yang Berpengaruh Terhadap Pemakaian Metode Kontrasepsi Implant di Kabupaten Sukoharjo. Stikes Aisyiyah Surakarta.

Maharani. 2010. Kesehatan Reproduksi Wanita. Jakarta: Trans Info Media

Notoatmodjo (2009). Metode penelitian kesehatan. Jakarta: Rineka Cipta.

Rowlands S, Searle S. 2014. Contraceptive implants: current perspectives. Dove Press Volume 2014:5 Pages 73-84. DOI https://doi.org/10.2147/OAJC. $\underline{\mathbf{S 5 5 9 6 8}}$

Saifuddin, Abdul Bari. 2014. Buku panduan praktis pelayanan kontrasepsi. Jakarta : Yayasan Bina Pustaka Sarwono Prawirohardjo.

Sarwono Prawirohardjo. 2011. Ilmu Kebidanan. Jakarta : PT Bina Pustaka Sarwono Prawirohardjo.

Sibagariang, Eva Ellya. 2010. Gizi dalam Kesehatan Reproduksi. Jakarta: Penerbit Buku Kesehatan 